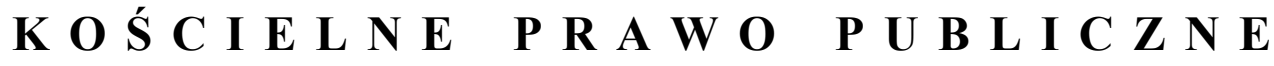

KOŚCIÓŁ I PRAWO 9(22) 2020, nr 2, s. 97-112

DOI: http://dx.doi.org/10.18290/kip2092-7

\author{
Oleksandr Bilash \\ Tetyana Karabin
}

\section{LEGAL REGULATION OF THE MILITARY CHAPLAINCY IN MODERN UKRAINE}

In the modern Ukrainian realities of contradictory public life, the fact that for several years in a row, according to sociological research, the Armed Forces of Ukraine $(62 \%)$ and the church $(61 \%)^{1}$ have one of the highest levels of trust in Ukrainian society is noticeable. For comparison: $46.1 \%$ do not trust the state apparatus and officials at all, and only $14 \%$ the Armed Forces of Ukraine. At the same time, it is paradoxical that the institution of military chaplaincy - the point of contact between the two institutions that enjoy the highest level of trust - is still at the stage of its formation and institutionalization. The long existence of military chaplaincy in Ukraine and on the territory of modern Ukraine since the time of the Zaporizhzhya Sich state [Holobuts'kyy 1994, 435], in the armies of the Russian Empire [Baimov 2015, 18-21], Austria-Hungary [Pylypiv and

OleKsandR BILASh, PH.D. - Department of Administrative, Financial and Information Law, Uzhhorod National University; e-mail: oleksandr.bilash@uzhnu.edu.ua; https://orcid.org/0000-0002-1248-7798

Tetyana Karabin, HAB. PH.D. - Department of Administrative, Financial and Information Law, Uzhhorod National University; e-mail: tetyana.karabin@uzhnu.edu.ua; https://orcid.org/0000-0002-6538-5269

${ }^{1}$ The level of trust to public institutions and the electoral orientations of the citizens of Ukraine: The investigation was conducted by the sociological service of the Razumkov Center on February 7-14, 2019, http://razumkov.org.ua/napriamky/sotsiologichni-doslidz hennia/riven-doviry-do-suspilnykh-instytutiv-ta-elektoralni-oriientatsii-gromadian-ukrainy [accessed:_20.11.2020]. 
Delyatyns'kyy 2018, 129-34], the Polish state [Ostanek 2019], Subcarpathian Rus as part of Czechoslovakia, the Ukrainian People's Republic, the Ukrainian Insurgent Army [Zabzalyuk 2012], the SS division 'Halychyna' [Lebedovych 1963] and the lack of proper legal regulation of this institution in recent Ukrainian history - the result of poor state policy, polyreligion and Soviet heritage of the state. At the same time, the revival of the attention of scientists, lawmakers, politicians, media and other active representatives of society to this issue is caused by several factors: 1) military and political factors (consolidation of the irreversibility of the strategic course of the state for Ukraine's full membership in the North Atlantic Treaty Organization, ${ }^{2}$ which requires the Ukrainian state to comply with NATO standards not only in rearmament and military management, but also the formation of appropriate conditions for the spiritual training of servicemen); 2) increasing the importance of the state defense sector, which is caused by the war in eastern Ukraine and requires the formation of a stable moral and psychological state of servicemen and their fighting spirit; 3 ) change of worldview and value paradigm in the state, accompanied by the introduction of real mechanisms for the realization of the right of servicemen to freedom of religion and performing religious sacraments. It is also pertinent to note here that this factor underlies the formation of the institute of pastoral care for student youth, prisoners and convicts, as well as in medical institutions; 4) the need to establish structural cooperation between the state and religious organizations, as well as between religious organizations themselves in a disparate multi-religious society.

\section{THE ESTABLISHMENT OF THE INSTITUTE OF CHAPLAINCY IN MODERN UKRAINE}

The Soviet period of the Ukrainian state's existence, of course, did not provide for any religious guardianship of servicemen, especially with the help of the institute of military chaplains. The possibility of forming such an institution arose after 1991, with the adoption of the basic law "On

\footnotetext{
${ }^{2}$ Law No. 2680-VIII of 7 February 2019 on Amendments to the Constitution of Ukraine, https://zakon.rada.gov.ua/laws/show/2680-19 [accessed: 20.11.2020].
} 
Freedom of Conscience and Religious Organizations," which is valid to this day and guarantees every citizen in Ukraine the right to freedom of conscience and provides the right to have, accept and change religion or belief by their choice, the freedom to profess any religion, alone or in association with others, not to profess any religion, to practice religious cults, to express openly and freely disseminate their religious or atheistic beliefs. ${ }^{3}$

However, this opportunity has not been fully realized in the military sphere, although Ukrainian military chaplains have been present in the contingent of peacekeepers since 1998, in particular, in Iraq, Kosovo, Sierra Leone and the Congo. The establishment of full-fledged military religious services in the 1990s was not in demand due to Ukraine's generally low military organization and inadequate attention to state security issues. Together with the research of scientists in various fields of knowledge conducted in this area [Afonin 1994; Zdioruk and Yaremchuk 1995; Mandrahelya 1995, 110], although mostly concerned the theoretical understanding of "the role of military chaplains in the army, their impact on the moral and psychological state of servicemen, analysis of the historical background and foreign experience of military chaplaincy" [Vasin $2017,96]$. Strategic stages for the future formation of pastoral care and service of military chaplains were also identified: 1) study of the possibilities of organizing pastoral care and chaplaincy service in the Armed Forces and other military formations of Ukraine, as well as preparation of improvements of Ukrainian legislation in this regard; 2) organization of pastoral care in the Armed Forces and other military formations of Ukraine with the help of civilian priests or pastors available in Ukrainian churches, as well as their retraining under special programs for the transition to the organization of military chaplaincy with simultaneous legislative support of this and the next stages; 3 ) practically and legally provided introduction of the Service of Military Chaplains in the Military Organization of Ukraine or substantiation of the inexpediency of such, proceeding from the previous stages [Zdioruk 2014].

At the same time, current regulation and adoption of legal acts of different legal force and level of imperative began in 2006 with the approval by the Minister of Defense of Ukraine of the directive "On

${ }^{3}$ Law of Ukraine No. 987-XII of 23 April 1991 on Freedom of Conscience and Religious Organizations, https://zakon.rada.gov.ua/laws/show/987-12\#Text [accessed: 15.11.2020]. 
Streamlining the Religious Needs of Servicemen of the Armed Forces of Ukraine" of April 21, 2006. ${ }^{4}$ Its provisions were initiated by the Minister of Defense to ensure respect for the constitutional rights and freedoms of servicemen of the Armed Forces of Ukraine and to regulate the mechanism of meeting the religious needs of religious servicemen before heads of military authorities, commanders of military units, military educational institutions, establishments and organizations of the Armed Forces of Ukraine to meet the religious needs of servicemen in the specifically listed forms (receiving blessings, conducting services, forming religious libraries, etc.). This document became essentially the first legal act designed to regulate the activities of the military pastorate.

Already in 2008, the Ministry of Defense of Ukraine and the authorized representatives of seven Churches and religious organizations of Ukraine signed a "Memorandum of Cooperation on Pastoral Care of Servicemen of the Armed Forces of Ukraine." The main purpose of the signing was to fix the intention to introduce in the Armed Forces of Ukraine an effective system of pastoral care and create an institution of military clergy (chaplaincy) to ensure the constitutional right of personnel to freedom of conscience and religion, creating a healthy psychological climate in military teams, families of servicemen, strengthening military patriotic education, the formation of principles of morality and spirituality, and creation of positive motivation for military service. ${ }^{5}$ This event is considered so significant that taking into account the experience of introducing military priesthood in the Armed Forces of Ukraine, some researchers distinguish two periods: before 2008 and after, and note that that year was a turning point, when unsystematic activities of churches and religious organizations gained consolidated interfaith cooperation, a "partnership between

\footnotetext{
${ }^{4}$ Directive of the Minister of Defense of Ukraine No. D-25 of 21 April 2006 on Streamlining the Religious Needs of Servicemen of the Armed Forces of Ukraine, https://www.mil.gov.ua/diyalnist/zvyazki-z-gromadskistyu/rada-u-spravah-dushpastirskoi -opiki-pri-ministerstvi-oboroni-ukraini/normativni-dokumenti-ta-metodichni-rekomendac zii/2014/07/08/direktiva-mou-pro-vporyadkuvannya-pitan-zadovolennya-religijnih-potrebvijskovosluzhbovcziv-zs/ [accessed: 21.11.2020].

${ }^{5}$ Memorandum of Cooperation on Pastoral Care of Servicemen of the Armed Forces of Ukraine of 2008, https://www.mil.gov.ua/diyalnist/zvyazki-z-gromadskistyu/rada-uspravah-dushpastirskoi-opiki-pri-ministerstvi-oboroni-ukraini/normativni-dokumenti-tametodichni-rekomendaczii/2014/07/08/memorandum-pro-spivpraczyu-u-spravah-dush pastirskoi-opiki-vijskovosluzhbovcziv-zs-ukraini/ [accessed: 21.11.2020].
} 
the army and religious organizations" has been established [Vladychenko $2014,182]$.

The signing of the memorandum was followed by several other events that reflected the consolidated cooperation between the state and religious organizations. Thus, in 2009 an advisory body - the Council for Pastoral Care at the Ministry of Defense of Ukraine was established. The purpose of this council is to implement practical measures aimed at the gradual introduction of an effective system of pastoral care in the Armed Forces of Ukraine and the establishment of the institute of military clergy (chaplaincy), coordination of interfaith cooperation in the Armed Forces of Ukraine, participation in discussions of draft laws and regulations on these issues, the implementation of charitable activities, etc. ${ }^{6}$ The work of this body was at one time very fruitful, a number of legal acts were developed, which were aimed at forming a legal mechanism to ensure the right of servicemen to meet religious needs, namely, "Conception of Pastoral Care in the Armed Forces of Ukraine," approved by Order of the Minister of Defense of Ukraine 2011, and "Guidelines for Military Authorities to Involve the Clergy of Those Churches (Religious Organizations) whose Believers Serve in the Armed Forces of Ukraine, to the Spiritual, Moral, Ethical and Military Patriotic Education," approved by the Ministry of Defense of Ukraine in February 2013.

\section{INSTITUTIONAL ARRANGEMENT OF THE CHAPLAINCY}

A qualitatively new stage in the development of legal regulation of the institution of the military clergy was the period beginning from 2014, which continues to this day. With the spreading of the Russian aggression against Ukraine, when the question of forming a combat-ready corps of the Armed Forces of Ukraine and other military formations arose, when real hostilities began to take place on the territory of the state, the issue of wide involvement of pastors in the army also became relevant. For "practicing chaplains," 2014 also became a milestone, dividing the development of chaplaincy in Ukraine into that which was in a peaceful life and the

${ }^{6}$ Order of the Ministry of Defense of Ukraine No. 115 of 17 March 2009 Regulation on the Council for Pastoral Care, https://ips.ligazakon.net/document/FIN62660 [accessed: 25.11.2020]. 
second - in real hostilities. ${ }^{7}$ Accordingly, legal regulation in the field of conceptions, memoranda and strategies has moved to legal acts of a higher degree of imperative.

Thus, the first and, unfortunately, the main of such acts was the order of the Cabinet of Ministers of Ukraine "On the Service of the Military Clergy (Chaplaincy) in the Armed Forces, the National Guard, the State Special Transport Service and the State Border Guard Service," which states that clergy, which are proposed by religious organizations and successfully selected, are employed with the conclusion of relevant employment contracts in the Armed Forces, the National Guard, ${ }^{8}$ the State Special Transport Service and the State Border Guard Service, belong to the personnel of the Armed Forces, the National Guard, the State Special Transport Service and the State Border Guard and are military priests (chaplains). ${ }^{9}$ This act began the real standardization of the creation of appropriate staff positions in the Armed Forces and other government agencies and amendments to the Classifier of Professions. Although, as researchers note, standardization of this level is catastrophically insufficient, it "creates additional dangers in the implementation of the absolutely necessary system of morale and combat support of Ukrainian troops by means of military chaplaincy" [Zdioruk 2016, 212].

Currently, as of January 2020, there are 116 chaplains positions in the Armed Forces, although only 85 have been filled, of which the Orthodox Church of Ukraine is represented by 55 priests, the Ukrainian Greek Catholic Church has 17 representatives, and the Ukrainian Free Church of Evangelical Christians - 6, Ukrainian Orthodox Church - one. ${ }^{10}$ Unfortunately, Muslim representatives do not obtain any chaplain's position in

${ }^{7}$ Zavdannya kapelana - zakhyshchaty lyudyanist'. Spivrozmovnyk - kapelan o. Andriy Zelins'kyy, http://oranta.org/index.php?option=com_content\&view=article\&id= 3452:zavdannja-kapelana-zahyshchaty-ljudjanist\&catid=27:gk-v-ukrajini-cat\&Item id=00000000057 [accessed: 25.11.2020].

${ }^{8}$ The National Guard of Ukraine is a military formation with law enforcement functions, which is part of the system of the Ministry of Internal Affairs of Ukraine.

${ }^{9}$ Order of the Cabinet of Ministers of Ukraine No. 677-r of 2 July 2014 on the Service of the Military Clergy (Chaplaincy Service) in the Armed Forces, the National Guard, the State Special Transport Service and the State Border Guard Service, https://zakon.rada.gov.ua/laws/show/677-2014-p\#Text [accessed: 25.11.2020].

${ }^{10}$ U Zbroynykh Sylakh na kapelans'kiy sluzhbi - 85 svyashchennykiv, https://armyi nform.com.ua/2020/01/u-zbrojnyh-sylah-na-kapelanskij-sluzhbi-85-svyashhennykiv/ [accessed: 30.11.2020]. 
the army, but six imams go to their faithful to the front [Yaremchuk 2019, 51]. At the same time, the service of chaplains in the Armed Forces in the east of the country is carried out on the principle of rotations, and according to the Ministry of Defense of Ukraine from the beginning of the war until the end of 2018 there were almost 5 thousand rotations of clergy. ${ }^{11}$ There are currently 30 military priests (chaplains) in the National Guard of Ukraine in full-time positions in various military formations. ${ }^{12}$

The first normative definition of the term "military priest" or "chaplain" is given in the Regulations on the Service of Military Clergy in the Armed Forces of Ukraine, which states that these are individuals who have a spiritual education, are clergymen of a religious organization registered in Ukraine, selected and accepted work for positions of employees of military units, military educational institutions, establishments and organizations of the Armed Forces of Ukraine to meet the religious needs of personnel. ${ }^{13}$ Similar provisions have been adopted for the chaplaincy service in the National Guard of Ukraine, ${ }^{14}$ the State Border Guard Service ${ }^{15}$ and the State Special Transport Service. ${ }^{16}$ The provisions of the relevant regulatory acts determine the legal status of chaplains and are similar in content. By the

${ }^{11}$ V armiyi proyshly rotatsiyu mayzhe p'yat' tysyach kapelaniv - Henshtab, https:// www.ukrinform.ua/rubric-ato/2609554-v-armii-projsli-rotaciu-majze-pat-tisac-kapelaniv -genstab.html [accessed: 30.11.2020].

${ }^{12}$ Kerivnyk viddilu dushpastyrstva Departamentu viys'kovoho kapelanstva UHKTS vidvidav 2 Halyts'ku bryhadu NHU, http://ngu.gov.ua/ua/news/kerivnyk-viddilu-dush pastyrstva-departamentu-viyskovogo-kapelanstva-ugkc-vidvidav-2-galycku-brygadu [accessed: 30.11.2020].

${ }^{13}$ Order of the Ministry of Defense of Ukraine No. 685 of 14 December 2016 on the Adoption of the Regulation on Military Clergy Service (Chaplaincy Service) in the Armed Forces of Ukraine, https://zakon.rada.gov.ua/laws/show/z0010-17\#Text [accessed: 30.11.2020].

${ }^{14}$ Order of the Ministry of Internal Affairs of Ukraine No. 205 of 24 March 2016 on the Adoption of the Regulation on Military Clergy Service (Chaplaincy Service) in the National Guard of Ukraine, https://zakon.rada.gov.ua/laws/show/z0557-16\#Text [accessed: 30.11.2020].

${ }^{15}$ Order of the Ministry of Internal Affairs of Ukraine No. 1065 of 10 October 2016 on the Adoption of the Regulation on Military Clergy Service (Chaplaincy Service) in the State Border Guard Service of Ukraine, https://zakon.rada.gov.ua/laws/show/z14 30-16\#Text [accessed: 30.11.2020].

${ }^{16}$ Order of the Ministry of Infrastructure No. 201 of 6 June 2017 on the Adoption of the Regulation on Military Clergy Service (Chaplaincy Service) in the State Special Transport Service, https://zakon.rada.gov.ua/laws/show/z0793-17\#Text [accessed: 30.11.2020]. 
way, according to the press service of the Ministry of Internal Affairs of Ukraine, this department is willing to expand the chaplaincy to the National Police. ${ }^{17}$

A comparative analysis of the institute of chaplaincy of Ukraine with the countries of the European Union has already been carried out on the pages of scholarly publications [Kryvenko, Omelchuk, and Chernovaliuk 2020], however, some features are still worth dwelling on. In particular, in contrast to the legal status of chaplains in the Czech Republic, where they are officers [Tretera and Horák 2017], in Ukraine chaplains are employees of the Armed Forces, but their status differs from that of a serviceman. As in the Slovak Republic, chaplains hold positions in the relevant military units [Moravčiková 2019]. There are a number of requirements for them, in particular, he must be a citizen of Ukraine and a clergyman of a religious organization of Ukraine, must have a spiritual education, at least three years of experience as a clergyman, and speak the state language.

The general principles of the procedure for the appointment of military priests (chaplains) are settled by the Regulations on the Service of the Military Clergy (Chaplaincy) in the Armed Forces of Ukraine. Commissioners from religious organizations nominate clergy for the positions of military priests (chaplains), they are approved by the Security Service of Ukraine (Central Office or regional bodies of the Security Service of Ukraine, military counterintelligence bodies) and are hired by commanders of military units in accordance with the labor law of Ukraine. ${ }^{18}$ In contrast to the provisions of the legislation of the Czech Republic, which adheres to the principle of "time limit, and chaplains are usually appointed for a term of four years" [Tretera and Horák 2017], in Ukraine, military chaplains are replaced indefinitely.

In accordance with the cited provision, each religious organization independently carries out general theological training of candidates for the positions of military priests (chaplains) and organizes the provision of their cult property, official and spiritual literature. At the same time, military priests (chaplains) are also trained in a special program of military humanitarian and military psychological training. According to the

\footnotetext{
${ }^{17}$ Arsen Avakov: MVS za pidtrymky USA rozshyryuye instytut kapelanstva, https://mvs.gov.ua/ua/news/26063_Arsen_Avakov_MVS_za_pidtrimki_SSHA_rozshiryu _institut_kapelanstva.htm [accessed: 30.11.2020].

${ }^{18}$ Order of the Ministry of Defense of Ukraine No. 685.
} 
Public Relations Department of the Armed Forces of Ukraine, we are aware of the following two Basic training courses conducted during 20172018, which were successfully completed by 52 military priests (chaplains). ${ }^{19}$

A clergyman of one of the religious organizations, to which most of the believing servicemen and employees of the military unit (body, unit) belong, is appointed to the position provided by the staff list of the military unit (body, subdivision). When deciding on the determination of the religious organization from which the candidate for the position of military priest (chaplain) will be selected, the command of the military unit conducts an anonymous survey of the military unit personnel to determine the confessional affiliation of the personnel. The results of the anonymous survey are recorded in the protocol and taken into account when making a decision.

\section{PROSPECTS FOR THE DEVELOPMENT OF THE INSTITUTE OF CHAPLAINCY}

The current regulation of the institution of military chaplaincy by a government decree and departmental orders is obviously not sufficient and appropriate. As the positions of military chaplains are part of the staffs of military units (bodies, units), the issue of subordinate relations of military clergy with both military and religious leadership, the procedure for appointing and recalling a military clergyman, reporting, liability (including material), the possibility of selecting an assistant from the military, the procedure for addressing, greeting (for example, whether to pay military honor, to be held in hand, etc.), as well as the procedure for financing military clergy. These and other issues are addressed in the legal literature when justifying the adoption of a separate law that would regulate the institution of military chaplaincy [Kryvenko 2014, 97-98].

${ }^{19}$ Etapy stanovlennya sluzhby viys'kovoho dukhovenstva $v$ Zbroynykh Sylakh Ukrayiny, https://www.mil.gov.ua/news/2018/12/27/etapi-stanovlennya-sluzhbi-vijskov ogo-duhovenstva-v-zbrojnih-silah-ukraini/ [accessed: 30.11.2020]. 
Such a draft Law of Ukraine in 2019 was submitted to the Verkhovna Rada of Ukraine and adopted in the first reading as a basis. ${ }^{20}$ It proposes the creation of a military chaplaincy (military clergy service, chaplaincy service), in which the positions of military chaplains will not be part of the staffs of military units (bodies, units). According to the draft law developers, chaplaincy associations will be established in religious organizations to ensure the organization of military chaplaincy tasks, with which general agreements on pastoral care will be concluded, and military chaplains (military chaplains-volunteers) who will provide pastoral care will be subordinated to chaplains associations (religious associations). The recently mentioned, according to the draft law developers, on the one hand, will help ensure the constitutional rights of personnel of the Armed Forces, other military formations and law enforcement agencies of special purpose to freedom of thought and religion and, on the other hand, will comply with the Constitution and laws of Ukraine regarding the separation of church and religious organizations from the state. Without diminishing the positive aspects of the draft law, it should also be noted that its provisions on the payment of pastoral care are also inconsistent with the legislation of Ukraine, which does not allow funding of any organizations established on the basis of religion (part four of Art. 5 of the Law of Ukraine "On Freedom of Conscience and Religious Organizations").

An interesting point is that the draft law introduces the concept of "military chaplain-volunteer," who, if necessary to ensure the religious rites of religious servicemen and employees other than the religious affiliation of existing chaplaincy associations, can provide free pastoral care to personnel of the Armed Forces and other military formations. In our opinion, this approach is fair for several reasons. Firstly, we agree that, despite some progress in the practical interaction of military formations and religious organizations, the analysis of church activities suggests that they "do not contribute to the strengthening of tolerance and cooperation due to conflicts between them" [Zdioruk 2016, 212]. Secondly, as the Ministry of Defense will conclude general agreements with various chaplaincy associations, taking into account the needs of religious and military workers based on the results of an anonymous survey, there will

${ }^{20}$ Resolution of the Verkhovna Rada of Ukraine of 6 June 2019 on Adoption of the Draft Law of Ukraine on Military Chaplaincy as a Basis, https://zakon.rada.gov.ua/ laws/show/2746-19 [accessed: 28.11.2020]. 
be individual servicemen representing a minority religious group (such as Muslims) that will not be able to provide for their religious needs. That is why volunteer chaplains will perform the functions of pastors for such persons. And, thirdly, Ukraine already has a voluntary service, which continues to be conducted by representatives of various churches, united by a common goal to help, feed and protect those who need it [Nepipenko 2015, 74].

However, neither a military chaplain nor a military chaplain-volunteer under the provisions of the draft law may be a clergyman or pastor of a religious administration or center whose headquarters are outside Ukraine in a state that is legally recognized as having committed military aggression against Ukraine and/or temporarily occupied part of the territory of Ukraine. The mentioned provisions of the analyzed draft law possibly were the reason why this draft law in the second reading could not get a sufficient number of votes of parliamentarians and, accordingly, its consideration was postponed. It should also be noted that the exclusion of the Ukrainian Orthodox Church of the Moscow Patriarchate from participation in the chaplaincy movement of Ukraine is meaningful and planned. This is confirmed, in particular, by the provisions of Directive D-6 of 13 March 2020 "On the Organization of the Development of Doctrinal Documents of the Armed Forces of Ukraine," which aims to improve doctrinal documents on the training and application of the Armed Forces of Ukraine, other defense forces in accordance with modern standards and principles adopted in the armed forces of NATO member countries. According to this document, the Main Directorate for Moral and Psychological Support of the Armed Forces of Ukraine is tasked with developing by 30 September 2020 Doctrines on Pastoral Work in Joint Operations, and the joint working group includes representatives of the Center for Moral and Psychological Support of the Armed Forces of Ukraine, the Orthodox Church of Ukraine, the Ukrainian Greek Catholic Church, the Ukrainian Evangelical Church, the All-Ukrainian Union of Evangelical Baptists and the Ukrainian Church of Evangelical Christians.

Undoubtedly, the positive aspect of the introduced draft law, in our opinion, is a clear and detailed regulation of the rights and responsibilities of military chaplains and military chaplains-volunteers, organization of military chaplain activities, referral to the service and grounds for termination of military chaplain, funding of military chaplaincy and social pro- 
tection of military chaplains. Military chaplains and military chaplainsvolunteers will be subordinated to the chaplaincy or religious organizations of the respective confession in matters of religious life, spiritual and liturgical practice, preaching, internal guidelines of the relevant religious center and religious tradition. At the same time, they must comply with the agenda of the military unit and the requirements of the commander of the military unit of the Armed Forces and other military formations, which regulate the daily and combat and service activities of the military unit.

Finally, an important issue in the development of the chaplaincy in a heterogeneous religious environment in Ukraine is the need to ensure interreligious and interfaith representativeness. This was one of the reasons for rejecting the first draft law attempts to regulate the institution of chaplaincy. None of the draft laws would meet the religious needs of believers of all faiths serving in military formations and law enforcement agencies equally, and would jeopardize the advantage of one group of believing servicemen over others who would not be provided with pastoral care. ${ }^{21}$ Ukraine is not unique in this regard, as most European countries "identify and invite religious groups to provide military chaplains and participate in discussions on the distribution of relevant positions" [Tavala 2016, 39].

According to the above-cited Regulation on the Service of the Military Clergy (Chaplaincy) in the Armed Forces of Ukraine, in the case of problematic issues of interfaith relations between military priests of various religious organizations, such issues should be resolved by consensus. In case of impossibility to reach an agreement, the commander of the military unit shall make a decision on this issue taking into account the proposals submitted by the structural unit of the military administration body and authorized by religious organizations representatives whose military priests are parties to the conflict. However, minimizing such conflict situations, in our opinion, requires not only legal settlement, but also organizational. One of such attempts was the adoption of regulation support for the establishment of spiritual centers of the Armed Forces of Ukraine buildings and premises located on the territory of military towns or in the

${ }^{21}$ Conclusion of the Main Research and Expert Department on the draft Law of Ukraine "On Amendments to Certain Laws of Ukraine" (on the introduction of the institute of clergy (chaplains) in the military, law enforcement agencies) of 4 October 2013, https://ips.ligazakon.net/document/xh0w100a?an=\&ed $=\& d t m=\& l e=$ [accessed: 28.11.2020]. 
field, belong to state property and can be used to meet the religious needs of personnel of the Armed Forces, other military formations and may not belong to any religious organization or community. ${ }^{22}$ The functioning and use of spiritual centers is based on the principles of equal access to spiritual centers of representatives of various religious organizations registered and operating in accordance with current legislation of Ukraine and respect, equality, tolerance for servicemen and their families, as well as representatives of religious organizations of different religions.

\section{CONCLUSIONS}

Thus, it can be argued that the legal and institutional regulation of military chaplaincy in Ukraine is in its development stage. Modern Ukraine has gone through three steps of formation of this institution: a) the first stage from 1991 to 2008 was marked by the lack of systematic cooperation between the state and the church in the field of establishing pastoral service in the army; b) the second stage from 2008 to 2014 was characterized by the adoption of acts of strategic and declarative nature, which became the basis for the next stages of development; c) the third stage from 2014 continues to the present day, the central feature of the stage is the adoption of departmental regulations, standardization of the creation of appropriate staff positions in the Armed Forces of Ukraine and other government agencies.

There is a strong hope that the adoption of a separate law regulating the institute of military chaplaincy will be the beginning of a new stage of its development, but several attempts to regulate it failed (the last time in 2019 the Ukrainian parliament managed to pass the draft law only in the first reading). At the same time, efforts to properly organize and regulate pastoral work do not stop, but encounter a number of problems, including the following: a) heterogeneity of the religious environment and low level of religious tolerance - and the need to ensure the right to freedom of

${ }^{22}$ Order of the General Staff of the Armed Forces of Ukraine No. 417 of 20 November 2018 on Adoption of the Regulation on the Spiritual Centers of the Armed Forces of Ukraine, https://dovidnykmpz.info/zagalni/nakaz-heneral-noho-shtabu-zbroynykh-sylukrainy-vid-20-11-2018-417-pro-zatverdzhennia-polozhennia-pro-dukhovni-tsentry-zb roynykh-syl-ukrainy/ [accessed: 28.11.2020]. 
conscience and religion for every citizen; b) direct legislative prohibition on funding the activities of any organizations established on the basis of religion, - and the need for state financial support of chaplains in the Armed Forces; c) political will to limit the influence of the UOC in the Armed Forces and other military formations in the conditions of the Ukrainian and Russian war - and the obligation to ensure equal satisfaction of the religious needs of believers of all confessions without discriminating.

These and other questions have yet to be answered in order to establish proper legal regulation of the institute of military chaplaincy in Ukraine.

\section{REFERENCES}

Afonin, Eduard A. 1994. Stanovlennya Zbroynykh Syl Ukrayiny: sotsial'ni ta sotsial'nopsykholohichni problemy. Kyjiv: Interhrafik.

"Arsen Avakov: MVS za pidtrymky USA rozshyryuye instytut kapelanstva." 2019. https://mvs.gov.ua/ua/news/26063_Arsen_Avakov_MVS_za_pidtrimki_SSHA_rozshi ryu_institut_kapelanstva.htm [accessed: 30.11.2020].

Baimov, Ayrat G. 2015. "Voyennoye dukhovenstvo v Rossiyskoy imperii: kratkiy istorikograficheskiy obzor." Istoricheskiye, filosofskiye, politicheskiye i yuridicheskiye nauki, kul'turologiya i iskusstvovedeniye. Voprosy teorii i praktiki Tambov 57, no. 7:18-21.

"Etapy stanovlennya sluzhby viys'kovoho dukhovenstva v Zbroynykh Sylakh Ukrayiny.” 2018. https://www.mil.gov.ua/news/2018/12/27/etapi-stanovlennya-sluzhbivijskovogo-duhovenstva-v-zbrojnih-silah-ukraini/ [accessed: 30.11.2020].

Holobuts'kyy, Volodymyr. 1994. Zaporozke kozatstvo. Kyjiv: Vyshcha shkola.

"Kerivnyk viddilu dushpastyrstva Departamentu viys'kovoho kapelanstva UHKTS vidvidav 2 Halyts'ku bryhadu NHU.” 2020. http:/ngu.gov.ua/ua/news/kerivnykviddilu-dushpastyrstva-departamentu-viyskovogo-kapelanstva-ugkc-vidvidav-2-ga lycku-brygadu [accessed: 30.11.2020].

Kryvenko, Yuriy. 2014. "Diyal'nist' viys'kovykh kapelaniv za zakonodavstvom Ukrayiny." Prykarpats'kyy yurydychnyy visnyk 6, no. 3:96-98.

Kryvenko, Juliia, Oleksandr Omelchuk, and Iuliia Chernovaliuk. 2020. "Chaplaincy Institute in Ukraine and EU countries." Journal of Education Culture and Society 11 , no. 1:50-58.

Lebedovych, Ivan. 1963. Polevi dukhovnyky Ukrayins'koyi Halyts'koyi Armiyi: u 45richchya uchasty u Vyzvol'nykh zmahannyakh (Materialy do istoriyi). Winnipeg: Vydav o. Ivan Lebedovych.

Mandrahelya, Volodymyr. 1995. "Deyaki problemy adaptatsiyi dosvidu kapelanstva zakhidnykh armiy do ukrayins'kykh Zbroynykh Syl." In Armiya $i$ dukhounist': svoboda sovisti ta virovyznannya (Materialy mizhnarodnoyi naukovo-praktychnoyi konferentsiyi). Kyjiv: [no information about Publisher].

Moravčiková, Michaela. 2019. "State and Religion in the Slovak Republic." In State and Church in the European Union, ed. Gerhard Robbers, 563-612. Baden-Baden: Nomos Verlag. 
Nepipenko, Ludmila. 2015. "Viys'kovi svyashchenyky (kapelany) u suchasniy Ukrayini." Chest' $i$ zakon 53, no. 2:72-78.

Ostanek, Adam. 2019. "Pol's'ke viys'ko ta natsional'na polityka pol's'koyi vlady u L'vivs'komu, Stanislavivs'komu ta Ternopil's'komu voyevodstvakh u 1921-1926 rokakh." Ukrajina-Pol'shcha: istorychna spadshchyna i suspil'na svidomist 12:50-66.

Pylypiv, Ihor V., and Ruslan I. Delyatyns'kyy. 2018. "Instytut viys'kovykh kapelaniv v Ukrayini (XX-XXI st.): etapy rozvytku ta rol' u formuvanni ukrayins'koyi natsiyi." Naukovyy visnyk Hileya 134:129-34.

Tavala, Emanuel. 2016. "The juridical status of the chaplains in European armed forces." Jurnalul de Studii Juridice 3-4:23-41.

Tretera, Jiři R., and Záboj Horák. 2017. Religion and Law in the Czech Republic. Ed. 2. Alphen aan den Rijn: Wolters Kluwer.

"U Zbroynykh Sylakh na kapelans'kiy sluzhbi - 85 svyashchennykiv." 2020. https://armyinform.com.ua/2020/01/u-zbrojnyh-sylah-na-kapelanskij-sluzhbi-85svyashhennykiv/ [accessed: 30.11.2020].

"V armiyi proyshly rotatsiyu mayzhe p'yat' tysyach kapelaniv - Henshtab." 2018. https://www.ukrinform.ua/rubric-ato/2609554-v-armii-projsli-rotaciu-majze-pat-tisackapelaniv-genstab.html [accessed: 30.11.2020].

Vasin, Maksim. 2017. "Perspektyvy zakonodavchoho vrehulyuvannya vzayemodiyi derzhavy i relihiynykh orhanizatsiy u sferi vprovadzhennya viys'kovoho kapelanstva." Chasopys Kyyivs'koho universytetu prava 3:96-100.

Vladychenko, Larisa. 2014. "Dosvid uprovadzhennya viys'kovoho svyashchenstva (kapelanstva) u Zbroynykh sylakh Ukrayiny.” Skhid 1:180-85.

Yaremchuk, Serhiy. 2019. "Vzayemodiya tserkvy ta armiyi na prykladi vprovadzhennya kapelans'koyi sluzhby v Ukrayini." Relihiya ta Sotsium 35, no. 3:46-54.

Zabzalyuk, Dmytro. 2012. Dushpastyrs'ka sluzhba ukrayins'kykh viys'kovykh formatsiy pershoyi polovyny $X X$ st. L'viv: Lvivs'kyy derzhavnyy universytet vnutrishnikh sprav Ukrayiny.

"Zavdannya kapelana - zakhyshchaty lyudyanist'. Spivrozmovnyk - kapelan o. Andriy Zelins'kyy." 2017. http://oranta.org/index.php?option=com_content\&view=article \&id=3452:zavdannja-kapelana-zahyshchaty-ljudjanist\&catid=27:gk-v-ukrajini-c at\&Itemid=00000000057 [accessed: 25.11.2020].

Zdioruk, Serhiy I. 2014. "Sluzhba viys'kovykh kapelaniv u Voyenniy orhanizatsiyi Ukrayins'koyi Derzhavy: neobkhidnist', mozhlyvosti ta perspektyvy.” https://niss.gov. ua/sites/default/files/2014-07/Kapelany-3aa20.pdf [accessed: 01.12.2020].

Zdioruk, Serhiy I. 2016. "Polityko-pravovi problemy orhanizatsiyi sluzhby viys'kovykh kapelaniv Ukrayiny." Suspil'no-politychni protsesy 4:211-21.

Zdioruk, Serhiy I., and Vyacheslav D. Yaremchuk. 1995. Dukhovno humanitarni aspekty stratehiyi rozvytku viys'kovykh formuvan' Ukrayiny. Kyjiv: Natsional'nyy instytut stratehichnykh doslidzhen'.

\section{Legal Regulation of the Military Chaplaincy in Modern Ukraine}

\section{Summary}

This study explores the formation of legal regulation of the institute of chaplaincy in Ukraine. It includes an analysis of the stages of development of its regulation in the 
last thirty years. A number of topical issues were analyzed among others, the need to ensure the right to freedom of conscience and religion to every citizen in a diverse religious environment. There is a need for state financial support of chaplains in the Armed Forces. It should be raised the obligation to ensure equal satisfaction of the religious needs of believers of all confessions without discrimination in the conditions of the Ukrainian and Russian war and influences from the Russian Federation.

Key words: chaplain; legal regulation; freedom of religion; Armed Forces of Ukraine

\section{Regulacje prawne duszpasterstwa wojskowego we współczesnej Ukrainie}

\section{Streszczenie}

Niniejsze opracowanie dotyczy tworzenia regulacji prawnej duszpasterstwa wojskowego na Ukrainie. Zawiera analizę etapów jego rozwoju w ostatnich trzydziestu latach. W artykule przeanalizowano szereg aktualnych zagadnień m.in. konieczność zapewnienia prawa do wolności sumienia i wyznania każdemu obywatelowi w zróżnicowanym środowisku religijnym. Istnieje potrzeba wsparcia finansowego ze strony państwa kapelanów w Siłach Zbrojnych. Należy podnieść obowiązek zapewnienia równego zaspokojenia potrzeb religijnych wyznawców wszystkich wyznań bez dyskryminacji w warunkach wojny ukraińsko-rosyjskiej i wpływów Federacji Rosyjskiej.

Słowa kluczowe: kapelan; regulacje prawne; wolność religijna; Siły Zbrojne Ukrainy

Informacje o Autorze: DR OLEKSANDR BILASH - Katedra Prawa Administracyjnego, Finansowego i Informatycznego, Użhorodzki Uniwersytet Narodowy; e-mail: oleksandr.bilash@uzhnu.edu.ua; https://orcid.org/0000-0002-1248-7798

Informacje o Autorze: DR HAB. TETYANA KARABIN - Katedra Prawa Administracyjnego, Finansowego i Informatycznego, Użhorodzki Uniwersytet Narodowy; e-mail: tetyana.karabin@uzhnu.edu.ua; https://orcid.org/0000-0002-6538-5269 